\title{
Immunisation of neonates at high risk of hepatitis B in England and Wales: national surveillance
}

\author{
Sheila Polakoff, Elise M Vandervelde
}

\begin{abstract}
The results of a voluntary programme of immunisation against hepatitis $B$ in neonates at high risk (mother being positive for hepatitis $B$ surface antigen and without hepatitis $B$ e antibody or having had acute hepatitis $B$ late in pregnancy) are reported. The programme was offered in England and Wales from November 1982. Passive immunisation alone was available in the first six months of life until 1985, after which infants received passive and active immunisation from birth; in addition, some infants received passive immunisation for six months followed by a course of hepatitis B vaccine. All but a few infants received the first immunising dose within 48 hours after birth. Blood samples for analysing markers of hepatitis B virus were available at 1 year from 147 of the 223 infants given passive immunisation, 54 of the 72 given passive followed by active immunisation, and 102 of the $\mathbf{1 5 5}$ given passive and active immunisation at birth. At 1 year 11 of the $127(9 \%)$ infants given four or more doses of specific hepatitis B immunoglobulin were positive for hepatitis B surface antigen compared with four of the 20 given three or fewer doses; 11 had levels of hepatitis B surface antibody greater than 50 IU/1. Only one of the 54 infants given passive then active immunisation was positive for hepatitis B surface antigen at 1 year and four infants had low ( $\leqslant 50 \mathrm{IU} / \mathrm{l})$ levels of hepatitis B surface antibody. Four of the 102 infants who received passive and active immunisation at birth were positive for hepatitis B surface antigen. Two had received the full course of vaccine, whereas in the other two vaccination was incomplete or unstated. In 79 of the 89 infants who received a complete course of vaccination the level of hepatitis B surface antibody was known, and 70 had levels at 1 year greater than 100 IU/1. Reactions to immunisation were not severe at any age. The incidence of side effects was $8 \%$ for the immunoglobulin, $11 \%$ for the vaccine, and $9 \%$ when immunoglobulin and vaccine were given together.

Wider collaboration in the programme is requested.
\end{abstract}

\section{Introduction}

The earlier in life that infection with hepatitis B virus occurs the greater the possibility that it will lead to persistent carriage, which greatly increases the risk of cirrhosis or primary hepatic carcinoma in later life. ${ }^{12}$ More than $80 \%$ of infants whose mothers are carriers of the hepatitis $B$ surface antigen and also have the hepatitis $\mathrm{Be}$ antigen (a serological marker of high infectivity) become persistent carriers. This outcome is less common when the mother is negative for the hepatitis $\mathrm{B}$ e antigen and its antibody and rare if she is positive for antibody to hepatitis $\mathrm{B} \mathrm{e}$ antigen. ${ }^{3}$

In Britain the prevalence of carriers positive for hepatitis B surface and e antigens among female blood donors is probably no more than one in 15000 , so the risk of perinatal exposure leading to persistent carriage is small. The hazard is, however, greater in particular groups such as non-whites, among whom the prevalence of carriers is higher, and those who abuse drugs by injecting and the sexually promiscuous, who have a greater chance of being exposed to hepatitis $B$ virus.

The first clear evidence that vertical transmission could be prevented by immunisation was provided by a small controlled study and confirmed later by a large scale trial in Taiwan. ${ }^{45}$ The results suggested that a course of specific hepatitis B immunoglobulin had a protective efficacy of $75 \%$ and led to the development of immunity in about two thirds of protected infants when the first dose was given promptly after birth.

The results achieved in the ideal conditions of a trial are less easily attainable when prophylaxis is undertaken routinely, particularly when success depends on the prompt delivery of a material in limited supply and the neonates at high risk form a small proportion of the total and are distributed nation wide.

These considerations led to a decision to offer a structured routine of reporting expected births at high risk of hepatitis $\mathrm{B}$, delivering specific hepatitis $\mathrm{B}$ immunoglobulin, and monitoring the outcome. The plan was to begin with passive immunisation, which was the only prophylaxis available at the time, but to include active immunisation later if a trial, then in progress, proved its safety and efficacy. ${ }^{6}$ The offer was made nationally in England and Wales. ${ }^{7}$

\section{Patients and methods}

The background to the programme was described in articles in medical and nursing journals, and colleagues in the relevant specialties were invited to collaborate. ${ }^{7.9}$ The programme was coordinated at this unit.

Arrangements for implementing the programme were made locally by discussion among microbiologists, who usually acted as coordinators, and obstetricians and paediatricians. The obstetrician arranged for a blood sample to be taken at the first antenatal visit from any woman with a personal or family history suggestive of an increased risk of infection with hepatitis B virus or from an ethnic group other than Europid. The sample was sent for tests for hepatitis B surface antigen and, if positive results were obtained, for tests for hepatitis $\mathrm{Be}$ antigen and its antibody. In three regions all antenatal patients are screened routinely for hepatitis B surface antigen.

When results were positive for hepatitis $B$ surface antigen and negative for hepatitis $\mathrm{Be}$ antibody the obstetricians discussed with the woman the implications and the benefits of prophylaxis for the infant. They gave her a study card designed to cover the possibility of emergency delivery elsewhere and also informed their paediatric colleagues.

At the end of the sixth month of pregnancy the first 
dose of specific hepatitis B immunoglobulin, labelled with the mother's name and hospital number, was sent from this unit to the hospital, where it was stored at $4^{\circ} \mathrm{C}$ to await the birth. This dose was given as soon as possible after the birth, and the paediatrician arranged for further doses to be given and for follow up observations to be made by health visitors two days after each dose.

When specific hepatitis B immunoglobulin alone was used for prophylaxis further doses were despatched from this unit after receipt of the form relating to the previous dose. When the programme was changed to passive and active immunisation and hepatitis B vaccine was obtainable from hospital pharmacies the paediatrician gave the first dose of vaccine at the same time as the specific hepatitis $B$ immunoglobulin, but at a different site. Paediatricians were asked to complete and return forms to the unit with details of further doses of vaccine.

About a month before the infants' first birthday a letter and a blood sample pack were sent to the paediatrician from this unit. The same procedure was followed for each subsequent birthday.

Only passive immunisation in the first six months of life was available until 1985, when hepatitis B vaccine became licensed for infants of less than 6 months; passive and active immunisations were then started at birth. Some infants received active immunisation during their second six months of life after earlier passive immunisation.

Blood samples from the infants were tested for markers of hepatitis B virus at this reference laboratory.

\section{IMMUNISING AGENTS}

Specific hepatitis B immunoglobulin was obtained

TABLE I-Ethnic group of antenatal patients at high risk of transmitting hepatitis $B$ to their unborn children. Values are numbers of women

\begin{tabular}{|c|c|c|c|c|}
\hline \multirow[b]{2}{*}{ Ethnic group } & \multicolumn{3}{|c|}{ Clinical or serological category } & \multirow[b]{2}{*}{ Total } \\
\hline & $\begin{array}{l}\text { Acute hepatitis B } \\
\text { in third trimester }\end{array}$ & $\begin{array}{c}\text { Positive for } \\
\text { hepatitis B e antigen }\end{array}$ & $\begin{array}{l}\text { Negative for } \\
\text { hepatitis } \mathrm{B} \mathrm{e} \text { antigen and antibody }\end{array}$ & \\
\hline $\begin{array}{l}\text { White } \\
\text { Asian: }\end{array}$ & 35 & 45 & 23 & 103 \\
\hline Chinese and Vietnamese & & 214 & 57 & 271 \\
\hline Philippine & & 5 & 2 & 7 \\
\hline Japanese & & 3 & 2 & 5 \\
\hline Other & 1 & 114 & 93 & 208 \\
\hline West Indian & & 2 & 3 & 5 \\
\hline African & 1 & 31 & 21 & 53 \\
\hline Not stated & 5 & 22 & 12 & 39 \\
\hline Total & 42 & 436 & 213 & 691 \\
\hline
\end{tabular}

TABLE II-Serological state at 1 year of 147 infants given only passive immunisation against hepatitis $B$ according to their mother's category of risk

\begin{tabular}{|c|c|c|c|c|}
\hline \multirow{2}{*}{$\begin{array}{l}\text { Serological state } \\
\text { of infant } \\
\text { at } 1 \text { year }\end{array}$} & \multicolumn{3}{|c|}{ Mother's category of risk } & \multirow[b]{2}{*}{ Total } \\
\hline & $\begin{array}{c}\text { Positive for } \\
\text { hepatitis } \mathrm{B} \text { e antigen }\end{array}$ & $\begin{array}{c}\text { Negative for } \\
\text { hepatitis B e antigen and antibody }\end{array}$ & $\begin{array}{l}\text { Acute hepatitis B } \\
\text { in third trimester }\end{array}$ & \\
\hline \multicolumn{5}{|c|}{ Four or more doses of $H B s I g$} \\
\hline $\begin{array}{l}\text { Positive for HBsAg } \\
\text { HBsAb: }\end{array}$ & 8 & & 3 & 11 \\
\hline $\begin{array}{l}\text { Negative } \\
>50 \text { IU } / 1 \\
\text { Unknown value }\end{array}$ & $\begin{array}{r}66 \\
7 \\
1\end{array}$ & 36 & $\begin{array}{l}5 \\
1\end{array}$ & $\begin{array}{r}107 \\
8 \\
1\end{array}$ \\
\hline Total & 82 & 36 & 9 & 127 \\
\hline \multicolumn{5}{|c|}{ Three or fewer doses of HBsIg } \\
\hline $\begin{array}{l}\text { Positive for } \mathrm{HBsAg} \\
\mathrm{HBsAb} \text { : }\end{array}$ & 3 & 1 & & 4 \\
\hline $\begin{array}{l}\text { Negative } \\
>50 \text { IU } / 1\end{array}$ & $\begin{array}{l}5 \\
4\end{array}$ & $\begin{array}{l}4 \\
1\end{array}$ & 2 & $\begin{array}{r}11 \\
5\end{array}$ \\
\hline Total & 12 & 6 & 2 & 20 \\
\hline
\end{tabular}

HBslg= Specific hepatitis B immunoglobulin. $\mathrm{HBsAg}=$ Hepatitis B surface antigen. HBsAb=Hepatitis B surface antibody.

${ }^{\star}$ None or trace amounts. †Not tested at Virus Reference Laboratory, London from the Blood Products Laboratory, Elstree, United Kingdom. Each phial of the paediatric preparation contained $100 \mathrm{mg}$ protein in $1 \mathrm{ml}$. The titres of hepatitis B surface antibody of the three batches used were: $\mathrm{GH} 16,137 \mathrm{IU} / \mathrm{ml}$; GH19, $110 \mathrm{IU} / \mathrm{ml}$; and $\mathrm{GH} 33$, $128 \mathrm{IU} / \mathrm{ml}$. Emergency doses were supplied for some infants by local public health laboratories from stocks of adult doses.

The first dose was $200 \mathrm{mg}$ as soon as possible after birth, and within 48 hours, by deep intramuscular injection. Six subsequent doses of $100 \mathrm{mg}$ were given every month.

Hepatitis B vaccine (H-B-Vax, Merck Sharp and Dohme) was given as three doses of $0.5 \mathrm{ml}(10 \mu \mathrm{g})$, the first as soon as possible after birth, the second one month later, and the third at 6 months.

\section{TESTS FOR MARKERS OF HEPATITIS B VIRUS}

Tests for hepatitis B surface and e antigens and hepatitis $B$ e antibody in serum samples from antenatal patients were performed locally by methods in routine use. Tests for hepatitis B e antigen and antibody were performed by public health laboratories by radioimmunoassay or enzyme linked immunoassay for their own associated hospitals and for local laboratories that did not do these tests.

Serum samples from infants were tested by radioimmunoassay at this reference laboratory for hepatitis B surface antigen, ${ }^{10}$ hepatitis B surface antibody (Ansab, Abbott Laboratories), hepatitis $\mathrm{Be}$ antigen and antibody, ${ }^{11}$ and hepatitis B core antibody. ${ }^{12}$ The results for the hepatitis $B$ antibodies are given in IU/l.

\section{Results}

The surveillance started in November 1982. Consultants in 85 hospitals collaborated in 1983; the numbers increased to 126 in 1984, 144 in 1985, and 167 in 1986.

By the end of June 1987, 691 antenatal patients whose newborn infants would be at high risk of becoming persistent carriers of hepatitis B surface antigen had been reported: 42 had acute hepatitis B in the third trimester, 436 were positive for hepatitis $\mathrm{B} \mathrm{e}$ antigen, and 213 were negative for both hepatitis $\mathrm{Be}$ antigen and hepatitis $\mathrm{Be}$ antibody. Table I shows the ethnic groups of the patients.

By the end of June 1987 one patient had miscarried and 51 had not yet delivered. Of the 639 infants who had been born, 618 were reported to have received prophylaxis. Of these, 157 were not yet 1 year by the time of the analysis and seven had died. Among the remaining 454, 223 had received only specific hepatitis $\mathrm{B}$ immunoglobulin in their first year, 72 had been given specific hepatitis B immunoglobulin in the first six months, after which a course of hepatitis B vaccine was begun, and 155 were given passive and active immunisation from birth.

\section{INFANTS GIVEN PASSIVE IMMUNISATION ALONE IN} THEIR FIRST YEAR

Blood samples were taken at 1 year from 147 of the 223 infants who had received specific hepatitis $B$ immunoglobulin but no hepatitis $B$ vaccine. The first dose of specific hepatitis B immunoglobulin was given to 81 infants within 12 hours after birth and to all but four within 48 hours after birth. Four or more doses were given to 127 of the 147 infants during the first year. Eleven of them $(9 \%)$ were positive for hepatitis B surface antigen: eight had mothers who were positive for hepatitis $\mathrm{Be}$ antigen and three had mothers who had had acute hepatitis B in the third trimester (table II). A larger proportion of infants who received three or fewer doses of specific hepatitis B immunoglobulin were positive for hepatitis B surface antigen 
TABLE III-Serological state at 2 years of 80 infants given only passive immunisation against hepatitis $B$ in their first year and varying amounts of hepatitis $B$ vaccine in their second

\begin{tabular}{|c|c|c|c|c|c|}
\hline \multirow{2}{*}{$\begin{array}{l}\text { Hepatitis B } \\
\text { vaccine } \\
\text { in second year }\end{array}$} & \multicolumn{4}{|c|}{ Serological state at 2 years } & \multirow[b]{2}{*}{ Total } \\
\hline & Positive for $\mathrm{HBsAg}$ & $\mathrm{HBsAb} \leqslant 50 \mathrm{IU} / 1$ & $\mathrm{HBsAb}>50 \mathrm{IU} / 1$ & HBsAb unknown* & \\
\hline \multicolumn{6}{|c|}{$H B s A g$ positive at 1 year } \\
\hline None & 4 & & & 2 & 6 \\
\hline \multicolumn{6}{|c|}{ Negative for hepatitis $B$ antibodies at $l$ yeart } \\
\hline $\begin{array}{l}\text { Full course } \\
\text { Delayed start } \\
\text { None }\end{array}$ & $\begin{array}{l}2 \\
5 \\
2\end{array}$ & $\begin{array}{l}3 \\
3\end{array}$ & $\begin{array}{r}51 \\
1\end{array}$ & & $\begin{array}{r}56 \\
9 \\
2\end{array}$ \\
\hline Total & 9 & 6 & 52 & & 67 \\
\hline \multicolumn{6}{|c|}{$H B s A b>50 I U / l$ at 1 year } \\
\hline $\begin{array}{l}\text { Full course } \\
\text { None } \\
\text { Not stated }\end{array}$ & & & $\begin{array}{l}5 \\
1\end{array}$ & 1 & $\begin{array}{l}5 \\
1 \\
1\end{array}$ \\
\hline Total & & & 6 & 1 & 7 \\
\hline
\end{tabular}

$\mathrm{HBs} \mathrm{Ag}=$ Hepatitis B surface antigen. $\mathrm{HBsAb}=$ Hepatitis B surface antibody.

* Not tested at Virus Reference Laboratory, London.

†No or only trace amounts of HBsAb or hepatitis B core antibody.

(4/20), but the difference was not significant. Few infants had levels of hepatitis B surface antibody greater than $50 \mathrm{IU} / 1$.

Blood samples were taken from 80 of the 147 children at 2 years (table III). Of six who were positive for hepatitis B surface antigen at the end of their first year, two were said to have formed antibodies, but their levels of hepatitis B surface antibody were not reported. One of these children has subsequently been tested twice and been found to have hepatitis B surface antibody $(>100 \mathrm{IU} / \mathrm{l})$ on each occasion. Of the 67 children who had no or only trace amounts of hepatitis B surface or core antibody at 1 year, nine had become carriers of hepatitis B surface antigen. Of these, two had received no hepatitis $B$ vaccine and in five the start of vaccination was delayed. None of the seven children with high levels of hepatitis B surface antibody at 1 year was positive for hepatitis B surface antigen.

\section{INFANTS GIVEN PASSIVE IMMUNISATION IN THEIR} FIRST SIX MONTHS THEN VACCINATION

Samples were collected at 1 year from 54 of the 72 infants given specific hepatitis B immunoglobulin in their first six months then hepatitis B vaccine. Only one infant was positive for hepatitis B surface antigen (table IV); he had been given his first dose within 24 hours after birth. Four infants had low levels of hepatitis B surface antibody.

Samples were collected from 32 of the 54 children at 2 years. The one infant positive for hepatitis B surface antigen remained so. Of the four infants who had had low levels of hepatitis B surface antibody, two developed high concentrations and all 27 infants with high levels of this antibody at 1 year retained them at 2 years.

\section{INFANTS GIVEN PASSIVE AND ACTIVE IMMUNISATION FROM BIRTH}

Samples were collected at 1 year from 102 of the 155 infants given specific hepatitis B immunoglobulin and hepatitis B vaccine from birth. Of these, 89 had been given a full course of hepatitis $B$ vaccine (table $V$ ). Only two of these were positive for hepatitis B surface antigen. Among infants with incomplete or inadequately recorded vaccination, two were positive for hepatitis B surface antigen. All four infants who were positive for the surface antigen were born to mothers positive for hepatitis $B$ e antigen and all had received specific hepatitis $B$ immunoglobulin within 48 hours after birth.
Of the 89 infants given three doses of vaccine, 79 were tested for hepatitis B surface antibody at the Central Public Health Laboratory and 70 had a level greater than $100 \mathrm{IU} / \mathrm{l}$; three had levels between 50 and $100 \mathrm{IU} / 1$, three between 10 and $50 \mathrm{IU} / 1$, and three had no detectable antibodies (table V). The antibody levels of the eight tested elsewhere were not reported.

Samples were taken from 11 out of 33 infants who had reached 2 years during the study. In all 11 the antibody level at 1 year had been greater than $100 \mathrm{IU} / 1$. At 2 years the levels in two of these children decreased to between 10 and $50 \mathrm{IU} / 1$.

\section{REACTIONS TO IMMUNISATION}

Follow up visits were made after 1222 of the 1485 ( $82 \%$ ) doses of specific hepatitis B immunoglobulin,

TABLE IV-Markers of hepatitis $B$ virus at $l$ year in 54 infants given passive immunisation in first six months then varying doses of hepatitis $B$ vaccine

\begin{tabular}{|c|c|c|c|c|}
\hline \multirow{2}{*}{$\begin{array}{c}\text { Marker of } \\
\text { hepatitis B virus } \\
\text { at } 1 \text { year }\end{array}$} & \multicolumn{3}{|c|}{ No of doses of hepatitis B vaccine before 1 year } & \multirow[b]{2}{*}{$\begin{array}{c}\text { Total } \\
(n=54)\end{array}$} \\
\hline & $\begin{array}{c}\text { Three } \\
(n=27)\end{array}$ & $\begin{array}{c}\text { Two } \\
(n=26)\end{array}$ & $\begin{array}{c}\text { One } \\
(n=1)\end{array}$ & \\
\hline \multicolumn{5}{|c|}{ Mother: $H B e A g$ positive } \\
\hline $\begin{array}{l}\text { HBsAg } \\
\text { HBsAb: }\end{array}$ & & 1 & & 1 \\
\hline$\leqslant 50 \mathrm{IU} / 1$ & 1 & 2 & & 3 \\
\hline$>50 \mathrm{IU} / \mathrm{l}$ & 16 & 11 & & 27 \\
\hline Unknown value & 1 & & & 1 \\
\hline Total & 18 & 14 & & 32 \\
\hline
\end{tabular}

\begin{tabular}{|c|c|c|c|c|}
\hline \multicolumn{5}{|c|}{ Mother: $H B e A g$ and $H B e A b$ negative } \\
\hline $\begin{array}{l}\text { HBsAb: } \\
>50 \text { IU } / 1\end{array}$ & 6 & 11 & & 17 \\
\hline Total & 6 & 11 & & 17 \\
\hline \multicolumn{5}{|c|}{ Mother: acute hepatitis $B$ in third trimester } \\
\hline $\begin{array}{l}\text { HBsAb: } \\
\quad \leqslant 50 \text { IU } / 1 \\
>50 \text { IU } / 1 \\
\text { Unknown value* }\end{array}$ & $\begin{array}{l}2 \\
1\end{array}$ & 1 & 1 & $\begin{array}{l}1 \\
3 \\
1\end{array}$ \\
\hline Total & 3 & 1 & 1 & 5 \\
\hline
\end{tabular}

$\mathrm{HBeAg}=$ Hepatitis $B$ e antigen. $\mathrm{HBs} A \mathrm{~g}=$ Hepatitis $B$ surface antigen. antigen. ${ }^{\star}$ Not tested at Virus Reference Laboratory, London.

TABLE V-Markers of hepatitis $B$ virus at 1 year in 102 infants given passive and active immunisation at birth

\begin{tabular}{|c|c|c|c|c|}
\hline \multirow{2}{*}{$\begin{array}{l}\text { Marker of } \\
\text { hepatitis B virus } \\
\text { at } 1 \text { year }\end{array}$} & \multicolumn{3}{|c|}{ No of doses of hepatitis B vaccine given } & \multirow[b]{2}{*}{$\begin{array}{c}\text { Total } \\
(n=102)\end{array}$} \\
\hline & $\begin{array}{l}\text { Three } \\
(n=89)\end{array}$ & $\begin{array}{l}\text { Two } \\
(n=3)\end{array}$ & $\begin{array}{l}\text { Not stated } \\
(n=10)\end{array}$ & \\
\hline \multicolumn{5}{|c|}{ Mother: $H B e A g$ positive } \\
\hline $\begin{array}{l}\text { HBsAg } \\
\text { HBsAb: }\end{array}$ & 2 & 1 & 1 & 4 \\
\hline $\begin{array}{l}\leqslant 50 \mathrm{IU} / 1 \\
>50 \mathrm{IU} / 1 \\
\text { Unknown value }^{\star}\end{array}$ & $\begin{array}{r}3 \\
46 \\
6\end{array}$ & 1 & 6 & $\begin{array}{r}3 \\
53 \\
6\end{array}$ \\
\hline Total & 57 & 2 & 7 & 66 \\
\hline \multicolumn{5}{|c|}{ Mother: $\mathrm{HBeAg}$ and $\mathrm{HBeAb}$ negative } \\
\hline $\begin{array}{l}\text { HBsAb: } \\
\quad \leqslant 50 \text { IU } / 1 \\
>50 \text { IU } / 1 \\
\text { Unknown value* }\end{array}$ & $\begin{array}{r}3 \\
25 \\
1\end{array}$ & & $\begin{array}{l}1 \\
2\end{array}$ & $\begin{array}{r}4 \\
27 \\
1\end{array}$ \\
\hline Total & 29 & & 3 & 32 \\
\hline \multicolumn{5}{|c|}{ Mother: acute hepatitis in third trimester } \\
\hline $\begin{array}{l}\text { HBsAb: } \\
>50 \text { IU/1 } \\
\text { Unknown value }\end{array}$ & $\begin{array}{l}2 \\
1\end{array}$ & 1 & & $\begin{array}{l}3 \\
1\end{array}$ \\
\hline Total & 3 & 1 & & 4 \\
\hline
\end{tabular}

$\mathrm{HBeAg}=$ Hepatitis $\mathrm{B}$ e antigen. $\mathrm{HBs} A \mathrm{~g}=$ Hepatitis $\mathrm{B}$ surface antigen $\mathrm{HBsA}=$ Hepatitis $\mathrm{B}$ surface antibody. HBeAb=Hepatitis $\mathrm{B}$ e antibody. *Not tested at Virus Reference Laboratory, London. 


\begin{tabular}{|c|c|c|c|c|c|c|c|}
\hline \multirow[b]{2}{*}{ Immunising agent } & \multirow{2}{*}{$\begin{array}{c}\text { No } \\
\text { of } \\
\text { doses }\end{array}$} & \multirow{2}{*}{$\begin{array}{l}\text { No of } \\
\text { follow up } \\
\text { visits }\end{array}$} & \multicolumn{4}{|c|}{ No $(\%)^{\star}$ of reactions } & \multirow[b]{2}{*}{ Total } \\
\hline & & & Soreness or swelling & Fever, malaise, or vomiting & Rash & Local and general & \\
\hline Specific hepatitis B immunoglobulin & 1485 & 1222 & $44(4)$ & $43(4)$ & $7(1)$ & & $94(8)$ \\
\hline Hepatitis $B$ vaccine & 783 & 509 & $33(7)$ & $23(5)$ & $1(<1)$ & & $57(11)$ \\
\hline Both & 313 & 251 & $19(8)$ & $2(1)$ & & $2(1)$ & $23(9)$ \\
\hline
\end{tabular}

^Incidence of reactions per follow up visit.

509 of the $783(65 \%)$ doses of hepatitis B vaccine, and 251 of the $313(80 \%)$ occasions when both passive and active immunisation were given. The incidence of any type of manifestation that might be considered to be a reaction was $8 \%$ for the immunoglobulin, $11 \%$ for the vaccine, and $9 \%$ for both at the start of active immunisation (table VI). No reaction was considered to be severe. Reactions to more than one dose were reported in 17 infants given specific hepatitis $B$ immunoglobulin and 11 given hepatitis $B$ vaccine.

\section{LOSSES TO FOLLOW UP}

Of the infants given specific hepatitis B immunoglobulin alone in their first year, 76 were not available for follow up at the end of the year, neither were 70 infants for whom a course of hepatitis $B$ vaccine had been started; 24 had moved abroad and at least 53 were known to have had full courses of vaccination.

\section{DEATHS}

Seven children died in infancy from causes entirely unrelated to immunisation. One death was due to the sudden infant death syndrome, which occurred more than four weeks after a dose of the immunoglobulin.

\section{Discussion}

Successful hepatitis B prophylaxis of newborn infants born to highly infective mothers depends on a prompt initial dose of specific immunoglobulin. ${ }^{13}$ This led to the incorporation in the programme of a structured system of reporting and despatch of specific hepatitis B immunoglobulin to await the birth. The effectiveness of the system, and of the clinicians' use of it, was shown by the results: all but a few of the infants were treated within 48 hours after the birth, most of them within 24 hours. With this important criterion fulfilled, the results of the various schedules could be compared with the results of immunisation trials.

A seven dose schedule of passive immunisation was chosen in preference to a three dose schedule as the results of a small trial suggested that it might be more effective. ${ }^{4}$ In the event, only about half of the infants received a full course, but the results for those who received four or more doses compared well with the results of the trial in that only $10 \%$ of infants born to highly infective mothers were positive for the antigen at 1 year. ${ }^{5}$ Less than a 10 th of the remainder developed immunity, however, compared with the two thirds predicted by the results of a trial..$^{14}$ Nevertheless, the outcome for children who were given a course of hepatitis B vaccine promptly in the second year was good, with $91 \%$ developing high levels of hepatitis B antibodies and only $4 \%$ becoming positive for the surface antigen, some of whom became negative in their second year and developed hepatitis antibody. In the infants who did not receive vaccine in their second year or whose course of vaccine was delayed the outcome was far less satisfactory, two thirds becoming positive for hepatitis B surface antigen. The frequent occurrence of antigenaemia among these infants suggests a breakthrough of persistent hepatitis $B$ virus infection, which was suppressed but not eliminated by the immunoglobulin rather than being a reinfection from later exposure to the mother.
The failure of so many infants to mount an immune response when given cover with specific hepatitis $B$ immunoglobulin emphasised the superior efficacy of passive and active immunisation. The results of the intermediate programme (passive immunisation followed by active after 6 months) were like those of the passive and active schedule from birth that succeeded it, both having a high protective efficacy similar to the findings of a trial ${ }^{6}: 90 \%$ of the infants in our study had high levels of protective antibody and only $4 \%$ were carriers of the surface antigen at 1 year. This high degree of protection applied only to infants whose courses of immunisation were completed: of the nine who did not or probably did not complete the course, two became positive for the antigen. As might be expected, a failure to complete the course was more common among those from whom a blood sample was not received at follow up. Clearly there are difficulties in conveying to parents, many of whom are recent immigrants with language and social problems, the importance of completing the course of immunisation.

Though the study results showed that $90 \%$ of fully immunised infants had high levels of protective antibody at 1 year, a longer period of observation is needed to find how long adequate levels will persist in these children in Britain, where opportunities for natural reinforcement by exposure to hepatitis $B$ virus are fewer than those possible in populations with a high prevalence of the virus. Further serial testing should help to answer this point.

Our results confirmed the safety of the two immunising agents: although reactions were reported after $11 \%$ of the doses of vaccine and $8 \%$ of the doses of the specific immunoglobulin none of these reactions was considered to be severe and none of the seven deaths was related in any respect to the immunisation.

A question not addressed by this surveillance is that of immunisation of infants born to low risk mothers positive for hepatitis $\mathrm{B}$ surface antigen and hepatitis $\mathrm{B} \mathrm{e}$ antibody. Though $10 \%$ of these infants are infected at birth, the outcome is almost always a transient antigenaemia followed by the development of immunity. The exposure rarely causes acute life threatening clinical hepatitis in early infancy but there has been concern about the frequency of cases reported from other countries. In Britain acute hepatitis of any type is uncommon in infancy; almost certainly such illnesses would be investigated to determine the type of viral infection and reported as most laboratories performing tests for markers of hepatitis B virus make weekly reports to the Central Public Health Laboratory. Our records for the past five years show only two infants with acute hepatitis B in early infancy. From this, the incidence would seem to be less than one in a million total births, or, estimating about 2000 births to women carrying the surface antigen in Britain each year, one in 5000 at risk. Apart from this small risk of serious infection at birth, it has been estimated that about $6 \%$ of infants born to mothers carrying hepatitis $\mathrm{Be}$ antibody may be exposed to siblings positive for the surface antigen, who were born when the mother was highly infective. ${ }^{\text {is }}$ This percentage however will decrease over time as the infants of high risk mothers are successfully immunised. 
Consideration of whether to extend immunisation against hepatitis B to infants of all mothers positive for hepatitis B surface antigen will need to take into account the resources of the hospital or the district in terms of the fivefold increase in workload which it is estimated that this would entail. In any event, differentiation of carriers by tests for hepatitis $\mathrm{B} \mathrm{e}$ antigen and antibody should be continued as priority should always be given to infants at high risk of persistently carrying hepatitis B surface antigen and later developing cirrhosis and primary hepatic carcinoma.

In conclusion, the programme has had one disappointing aspect, which is that so far consultants in only half of the hospitals with obstetric departments have collaborated. Hepatitis B vaccine is now readily available, stocks of specific hepatitis B immunoglobulin for immunisation are assured, and we hope that our successful results will encourage all those concerned to take part in future.

We thank all the members of the obstetric, paediatric, and microbiological teams who collaborated; and Mrs Valerie Little, Hepatitis Epidemiology Unit, who acted as assistant coordinator for the study and organised the computer analysis.

1 Beasley RP, Lin C-C, Hwang L-Y, Chien C-S. Hepatocellular carcinoma and hepatitis B virus: a prospective study of $22707 \mathrm{men}$ in Taiwan. Lancet 1981;ii:1129-33.
2 Sung J-L, Chen D-S. Maternal transmission of hepatitis B surface antigen in patients with hepatocellular carcinoma in Taiwan. Scand $\mathcal{f}$ Gastroentero 1980;15:321-4

3 Beasley RP, Trepo C, Stevens CE, Szmuness W. The e antigen and vertical transmission of hepatitis B surface antigen. Am $\mathcal{F}$ Epidemiol 1977; 105:94-8.

4 Reesink HW, Reerink-Brongers EE, Lafeber-Schut BJT, KalshovenBenschop J, Brummelhuis HGJ. Prevention of chronic HBsAg carrier state in infants of $\mathrm{HBs} A \mathrm{~g}$-positive mothers by hepatitis $\mathrm{B}$ immunoglobulin. Lancet 1979;ii:436-8.

5 Beasley RP, Hwang L-Y, Lin C-C, et al. Hepatitis B immune globulin (HBIG) efficacy in the interruption of perinatal transmission of hepatitis B virus carrier state. Initial report of a randomised double-blind placebo-controlled trial. Lancet 1981; ;ii:388-93.

6 Beasley RP, Hwang L-Y, Lee GC-Y, et al. Prevention of perinatally transmitted hepatitis B virus infections with hepatitis B immune globulin and hepatitis B vaccine. Lancet 1983;ii:1099-102.

7 Polakoff S. Immunisation of infants at high risk of hepatitis B. Br Med $\mathcal{J}$ 1982;285: 1294-5.

8 Polakoff S. Immunizing infants at high risk of hepatitis B. Health Visitor 1982;55:668.

9 Polakoff S. Transmission from mother to infant of hepatitis B virus infection Midwives Chronicle and Nursing Notes 1983 Jan:4-5.

10 Cameron CH, Combridge BS, Howell DR, Barbara JAJ. A sensitive immunoradiometric assay for the detection of hepatitis B surface antigen. 7 Virol Methods 1980;1:311-23.

11 Ferns RB, Tedder RS. Detection of both hepatitis Be antigen and antibody in a single assay using monoclonal reagents. F Virol Methods 1985;11:231-9.

12 Cohen BJ, Hewish RA, Mortimer PP. Comparison of radioimmunoassay and counter-immunoelectrophoresis for the detection of antibody to hepatitis B core antigen. $\mathcal{I}$ Virol Methods 1981;2:181-92.

13 Beasley RP, Stevens CE. Vertical transmission of $\mathrm{HBV}$ and interruption with globulin. In: Vyas GN, Cohen SN, Schmid R, eds. Viral hepatitis. Philadelphia: Franklin Institute Press, 1978:333-4

14 Beasley RP, Hwang L-Y, Stevens CE, et al. Efficacy of hepatitis B immun globulin for prevention of perinatal transmission of the hepatitis B virus carrier state: final report of a randomized double-blind placebo-controlled trial. Hepatology 1983;3:135-41.

15 Polakoff S. Immunoprophylaxis of infants born to hepatitis B virus exposed mothers. Arch Dis Child 1986;61:1242-3.

(Accepted 7 April 1988)

\section{Clinical comparison of extracorporeal shock wave lithotripsy and percutaneous nephrolithotomy in treating renal calculi}

Nicholas Mays, Sabri Challah, Swatee Patel, Edward Palfrey, Rosemary Creeser, Pragati Vadera, Peter Burney

\section{Abstract}

Study objective-To compare extracorporeal shock wave lithotripsy and percutaneous nephrolithotomy for efficacy in treating renal calculi.

Design-Non-randomised multicentre cohort study with 3 month follow up and 13 month data collection period.

Setting-Lithotripter centre in London, tertiary referral hospital, and urological clinics in several secondary and tertiary care centres.

Patients-933 of 1001 patients treated by lithotripsy at the lithotripter centre were compared with 195 treated by nephrolithotomy. Missing patients were due to incomplete collection of data. Age and sex distributions and characteristics of the stones were similar in the two treatment groups. Two patients died in the lithotripsy group. Three month follow up was achieved in about $84 \%$ of both groups (783/933 for lithotripsy; 163/195 for nephrolithotomy).

Interventions-The nephrolithotomy group had surgical nephrolithotomy alone. In the lithotripsy group $83 \%$ (774/933) had lithotripsy alone, 11\% (103/ 933) had combined lithotripsy and nephrolithotomy, and $6 \%(56 / 933)$ had lithotripsy plus ureteroscopy. Single and combined lithotripter treatments were analysed as one group and compared with nephrolithotomy.

End point-Presence of stones three months after treatment.

Measurements and main results-Presence of residual stones was assessed by plain radiography, ultrasonography, or intravenous urography. After adjustment for age and size and position of stone for patients with single stones the likelihood of being free of stones three months after treatment was significantly greater in the nephrolithotomy group than the lithotripsy group (odds ratio $6.6 ; 95 \%$ confidence interval 3.0 to 14.6 ) and the response was particularly pronounced with staghorn calculi $(62 \%$ $(8 / 13) v 15 \%(141 / 96)$ patients free of stones after nephrolithotomy and lithotripsy, respectively).

Other findings-19\% $(146 / 775)$ of patients who had had lithotripsy had to be readmitted within three months after treatment compared with $14 \%(23 / 162)$ who had nephrolithotomy; and 64\% (94/146) of readmissions after lithotripsy were for complications compared with $30 \%(7 / 23)$ of readmissions after nephrolithotomy.

Conclusions-Nephrolithotomy may be preferable to lithotripsy for treating renal stones and it may not be wise to invest heavily in lithotripsy facilities.

\section{Introduction}

Between 1985 and 1987 a single extracorporeal shock wave lithotripter was available to the NHS at St Thomas's Hospital, London. The Dornier machine at St Thomas's is an example of the first generation of the new technology of lithotripsy. It was joined in mid1987 by a second generation machine installed in Manchester by the North Western Regional Health Authority. Several other regional health authorities in England are currently considering the merits of purchasing their own second generation extracorporeal shock wave lithotripters for treating renal calculi. In these regions stones are currently removed by conventional open surgery or by percutaneous nephro- 